\title{
Translation, cultural adaptation, and content validity index of the Juvenile Love Scale to the Brazilian context
}

\author{
Lorrayne Stephane Soares1, Jonas Jardim de Paula1,2, Leandro Fernandes Malloy-Diniż,4, \\ Débora Marques de Miranda ${ }^{4,5}$, Danielle de Souza Costa ${ }^{1}$
}

\author{
1 Postgraduate Program in Molecular Medicine, School of Medicine, Federal University of Minas Gerais (UFMG), Belo Horizonte, MG, Brazil. \\ 2 Department of Psychology, Faculdade de Ciências Médicas de Minas Gerais (FCMMG), Belo Horizonte, MG, Brazil. \\ ${ }^{3}$ Department of Mental Health, School of Medicine, Federal University of Minas Gerais (UFMG), Belo Horizonte, MG, Brazil. \\ ${ }^{4}$ National Institute of Science and Technology of Molecular Medicine (INCT-MM), Belo Horizonte, MG, Brazil. \\ ${ }_{5}^{5}$ Department of Pediatrics, School of Medicine, UFMG, Belo Horizonte, MG, Brazil
}

Received: $11 / 22 / 2016$ - Accepted: 3/9/2017

DOI: 10.1590/0101-60830000000121

\begin{abstract}
Background: Passionate love involves physiological, emotional, and cognitive features that greatly changes behavior. This phenomenon seems universal or near universal. Even other animal species choose partners. An intense state of passionate love is associated with activity in dopamine pathways of the brain 'reward system', and recently has been regarded as a 'natural addiction'. Instruments or tools to evaluate romantic love during childhood is still scarce. Objective: To perform the translation and cultural adaptation of the Juvenile Love Scale (JLS) for use in the Brazilian context targeted for adolescents between 14 and 18 years old. Methods: The translation and cultural adaptation of JLS followed international recommendations, and its content validity was analyzed by a panel of experts in different areas of knowledge. Results: The final version of the JLS for use in the Brazilian context showed high content validity (> 90\%). Discussion: To our knowledge, this is the first scale for measuring romantic or passionate love in adolescents adapted to the Brazilian context. This instrument is a significant contribution to the study of the dimensions of love, as well as to understand the impact of love on the psychiatric phenomena that pervade life in this stage of development.
\end{abstract}

Soares LS et al. / Arch Clin Psychiatry. 2017;44(3):63-6

Keywords: Romantic love, passionate love, Juvenile Love Scale (JLS), psychometrics, adolescence assessment.

\section{Introduction}

Romantic love, or passionate love, is associated with an intense desire for union towards another person ${ }^{1}$. Passionate love involves physiological, emotional and cognitive features that greatly changes behavior. Although some consider romantic love as a cultural construct promoted by the European historical context, there is evidence that this phenomenon is universal or near universal. Jankowiak and Fischer ${ }^{2}$ analyzed 166 different societies and found reports of passionate love in $147(88.5 \%)$ of them. These results are endowed by evidence that behaviors related to romantic love are also observed in other animal species through partners' choice mechanisms ${ }^{3}$. Altogether, passionate love seems to have an evolutive component, which is related to motivation towards a preferred mating partner ${ }^{4}$.

An intense state of passionate love is associated with activity in dopamine pathways of the brain 'reward system' (e.g., ventral tegmental area, caudate, and accumbens), and recently has been regarded as a 'natural addiction', though with mainly positive effects'. However, individuals passionately in love often express non-adaptive behaviors when expressed in extremes such as euphoria, obsession, and risk-behavior, which may lead to harmful consequences, particularly for those experiencing love withdrawn/rejection ${ }^{5,6}$. In fact, intense romantic infatuation was proposed as a model for studying "normal" alteration of the mechanisms related to reward processing6, and has become an increasing topic of study ${ }^{7}$. Therefore, it is of extreme importance to be able to measure 'passionate love' reliably.

Hatfield et al. ${ }^{8}$ found 33 instruments measuring romantic love over the last 70 years approximately. These measures were elaborated by different areas of expertise such as Sociology, Psychology, Anthropology, Medicine, Biology and Neurosciences. However, two scales stand out as the most used to measure human love, namely the Sternberg's Triangular Love Scale and the Hatfield \& Sprecher's Passionate Love Scale (PLS). From the PLS, Hatfield and Sprecher also elaborated the Juvenile Love Scale (JLS) ${ }^{9}$. The purpose of the JLS is to measure romantic love in children and adolescents from 3 to 18 years-old. The juvenile version contemplates cognitive, physiological, and behavioral aspects of love. Despite the adult version had been translated into more than 12 languages and adapted to many other cultures and countries such as Germany, France, India, Italy, and even $\mathrm{Brazil}^{8}$, measures that consider the state of romantic love during childhood and adolescence are still scarce. Nevertheless, adolescence may be a critical sensitive period for the experience of love, a time when love intensity may be lived as in no other point in life, especially in late adolescence ${ }^{10,11}$. Puberty brings a cascade of changes putting adolescents at a higher risk of reckless behavior, especially in the face of social situations, making them especially driven by passions ${ }^{12,13}$. Therefore, to expand cross-cultural research on passionate love in adolescents is of relevance for its better characterization and further investigation of its influence on a range of adaptive and non-adaptive behaviors.

In this study, we present the translation and cultural adaptation of the Juvenile Love Scale-JLS for use in the Brazilian context. The Content Validity Index (CVI) is also shown for the JLS Brazilian version. The target population for the present adaptation was adolescents between 14 to 18 years.

\section{Methods}

\section{Juvenile Love Scale (JLS)}

Thirty items compose the JLS, which also has a reduced version with 15 items. The items are rated on a 9 points-Likert scale (from one to nine) with higher scores indicating higher love intensity. It can be used to assess romantic love intensity in children and adolescents from 3 to 18 years. Hatfield and Young ${ }^{13}$ reviewed evidence published in different studies and found high internal consistency with indexes ranging from 0.94 to 0.98 . The correlation between the JLS and the Passionate Love Scale, the adult version, is 0.88 for children and 0.87 for adults ${ }^{14}$. 
The JLS was designed to assess cognitive, emotional and behavioral signs of passionate love ${ }^{8,10}$. Cognitive components consist of [1] intrusive thought or concern for the partner; [2] idealization of the other or the relationship; and [3] desire to get to know each other and be known by him/her. The emotional components are [1] attraction to the partner, especially sexual; [2] positive feelings when things are going well; [3] negative feelings when things go wrong; [4] yearning for reciprocity; [5] desire for a whole and permanent union; and [6] physiological arousal (sexual). Finally, the behavioral components consist of [1] actions to determine the feelings of others; [2] studying the other person; [3] be at the disposition for the other; and $[4]$ the maintenance of physical proximity.

\section{Translation and adaptation}

The adaptation process of the original instrument to the Brazilian context occurred in six stages as recommended by Sousa and Rojjanasrirat ${ }^{14}$.

Stage 1. The translation of the original scale into Brazilian Portuguese was elaborated by two independent bilingual translators (T1 and T2).

Stage 2. A preliminary version was synthesized combining the best cultural translation of each item between T1 and T2. This first synthesis was performed by a third independent bilingual individual who was knowledgeable about the instrument and its theoretical foundation.

Stage 3. Two independent native English-speakers backtranslated the preliminary version from Brazilian Portuguese to American English.

Stage 4. The two back-translated versions were examined by a committee composed of bilingual clinical psychologists, English native speakers, and English teachers and translators in Brazil. They assessed the initial conceptual, semantic and content equivalence of both back-translated versions until reaching a final agreement. In this stage, only item 26 ("____ can make me feel bubbly, like coke.") had to go through the earlier stages again in order to be considered equivalent in both languages.

Stage 5. Twenty-two adolescents between 14 and 18 years participated in a pilot testing of the scale for assessment of the clarity of the instructions and items regarding language. Participants were asked to rate the instrument on a dichotomous scale (i.e., clear vs. unclear).

Stage 6. The preliminary final version was submitted to an expert committee of scholars and professionals to assess the content validity of the scale to elaborate a final version. Data regarding content validity was collected trough a questionnaire developed following the model suggested by Polit and Beck ${ }^{15}$. The items in the preliminary version of the scale were rated in a 4 point-Likert scale (1-irrelevant, 2-little relevance; 3-relevant; and 4-extremely relevant). Ten judges among scholars and professionals in the Psychology and Neuroscience fields answered the content validity questionnaire. We then calculated the Content Validity Index (CVI) per item and of the scale, i.e., the degree of agreement of the judges about the classification of the items ${ }^{15}$. For analysis, the rates were merged into two categories, so items ranked as 1 and 2 were considered irrelevant for the scale, while those scored as 3 and 4 were considered relevant. First, we calculated the CVI individually for each item (proportion of experts rating the item as relevant). The CVI of the whole scale was then obtained as the mean of the CVI of the items. Polit and Beck ${ }^{15}$ recommended values above 0.90 to achieve significant content validity.

All participants consented to have their data used in the research. The project was approved by the local ethics board (CAAE: 57272416.1.0000.5149).

\section{Results}

The pilot testing sample (stage 5) was composed by 22 adolescents from 14 to 18 years old ( $15.7 \pm 1.2$; 3 males, 19 females). All adolescents were students $(9.8 \pm 1.03$ years of education). The interrater agreement for the instructions and all items was higher than $80 \%$. Therefore, no item had to be reconsidered in this stage.

The expert committee was composed of ten individuals among four University professors (neuroscientists in university departments of Psychology [ $\mathrm{n}=2]$, Pediatrics, and Physical Education), four Clinical Psychologists coursing post graduation (one Ph.D. student in Neuropsychology, and three master students in Molecular Medicine), and two Clinical Neuropsychologists coursing their Ph.D. in Molecular Medicine. Table $1^{1}$ shows the Content Validity Index (CVI) per item and of the whole scale. Thirteen out of 30 items were rated as relevant by a $100 \%$ of the experts. The agreement in the remaining, but two items, ranged between $80 \%$ and $90 \%$. A CVI of $78 \%$ or higher is considered ideal for the item judgment ${ }^{15}$. Therefore, the items 4 (Sometimes I think it is fun just to see ___ move) and 22 (I want__ know me, know what I am thinking, what scares me and what I desire) were considered poor in content validity. The version of 30 -items of the scale obtained a $91 \%$ CVI, while the 15 -items version reached a $93 \%$ CVI. Therefore, overall, the complete and short versions had a satisfactory CVI. Table 2 presents the original item and its final cultural adaptation for the Brazilian population. Both versions are available to download in www.labepneuro.com or by the authors on demand.

\section{Discussion}

The translation and cultural adaptation of the Juvenile Love Scale (JLS) for use in the Brazilian context were executed under a rigorous methodological approach known to improve reliability and validity of cross-cultural instruments or scales ${ }^{16}$. The Brazilian version of the JLS showed good language clarity considering a

Table 1. Content Validity Index (CVI) of the Juvenile Love Scale items, complete version, and short version in the Brazilian context

\begin{tabular}{|c|c|c|c|c|c|}
\hline Item & CVI & Item & CVI & Item & CVI \\
\hline Item 1 & $80 \%$ & Item $11^{\mathrm{a}}$ & $100 \%$ & Item 21 & $90 \%$ \\
\hline Item $2^{\mathrm{a}}$ & $100 \%$ & Item 12 & $90 \%$ & Item $22^{\mathrm{a}}$ & $70 \%$ \\
\hline Item 3 & $90 \%$ & Item 13 & $100 \%$ & Item 23 & $100 \%$ \\
\hline Item 4 & $40 \%$ & Item $14^{\mathrm{a}}$ & $90 \%$ & Item $24^{\mathrm{a}}$ & $89 \%$ \\
\hline Item $5^{\mathrm{a}}$ & $90 \%$ & Item $15^{\mathrm{a}}$ & $100 \%$ & Item 25 & $90 \%$ \\
\hline Item $6^{\mathrm{a}}$ & $100 \%$ & Item 16 & $100 \%$ & Item 26 & $100 \%$ \\
\hline Item $7^{\mathrm{a}}$ & $100 \%$ & Item $17^{\mathrm{a}}$ & $80 \%$ & Item $27^{\mathrm{a}}$ & $90 \%$ \\
\hline Item $8^{\mathrm{a}}$ & $100 \%$ & Item 18 & $90 \%$ & Item 28 & $90 \%$ \\
\hline Item 9 & $80 \%$ & Item $19^{\mathrm{a}}$ & $100 \%$ & Item 29 & $100 \%$ \\
\hline Item $10^{\mathrm{a}}$ & $100 \%$ & Item 20 & $90 \%$ & Item $30^{\mathrm{a}}$ & $90 \%$ \\
\hline \multirow[t]{2}{*}{ Scale-CVI } & 30 itens & $91 \%$ & & & \\
\hline & 15 itens & $93 \%$ & & & \\
\hline
\end{tabular}

a Indicates inclusion on the JLS-15 short form. 
Table 2. Juvenile Love Scale items - Brazilian Portuguese version

\begin{tabular}{|c|c|c|}
\hline Item & Original Version & Brazilian Version \\
\hline 1. & When ___ is around I laugh and cry more often. & Quando ___ está por perto eu sorrio e choro mais vezes. \\
\hline 2. & $\begin{array}{l}\text { I feel like things would always be sad and gloomy if I had to live without } \\
\text { forever. }\end{array}$ & $\begin{array}{l}\text { Eu sinto que as coisas são sempre tristes e sombrias se eu viver sem ___ para } \\
\text { sempre. }\end{array}$ \\
\hline 3. & Sometimes I feel shaky all over when I see & Algumas vezes, eu me sinto bambo quando vejo \\
\hline 4. & Sometimes I think it is fun just to watch ___ move around. & Às vezes, eu acho divertido apenas ver ___ se mover. \\
\hline 5. & Did you ever keep thinking about ___ when you wanted to stop and couldn't? & $\begin{array}{l}\text { Você já continuou pensando em alguém, mesmo quando você queria parar e não } \\
\text { conseguiu? }\end{array}$ \\
\hline 6. & I feel happy when I am doing something to make ___ happy. & Eu me sinto feliz quando estou fazendo algo que faz ___ feliz. \\
\hline 7. & I would rather be with ___ than anybody else. & Eu prefiro estar com ___ do que com qualquer outra pessoa. \\
\hline 8. & I'd feel bad if I thought ___ liked somebody else better than me. & Eu fico triste se penso que ___ gosta de outra pessoa. \\
\hline 9. & No one else could like ___ as much as I do. & Ninguém poderia gostar de ___ tanto quanto eu. \\
\hline 10. & I want to know all I can about & Eu quero saber tudo que eu puder sobre \\
\hline 11. & I'd like___ to belong to me in every way. & Eu gostaria se ___ fosse minha (meu) de todas as formas. \\
\hline 12. & I will always like __. & Eu sempre vou gostar de \\
\hline 13. & I feel all happy inside when ___ looks at me and I look at ___. & Eu me sinto todo feliz por dentro quando ___ olha para mim e eu olho para \\
\hline 14. & played with me all the time. & Eu realmente adoraria se ___ brincasse comigo o tempo todo. \\
\hline 15. & If I could, when I grow up I'd like to marry (live with) & Se eu puder, quando crescer, gostaria de me casar (viver) com \\
\hline 16. & __ is the person who can make me feel the happiest. & __ é a pessoa que me faz mais feliz. \\
\hline 17. & When ___ hugs me my body feels warm all over. & Quando ___ me abraça, eu sinto todo meu corpo se aquecer. \\
\hline 18. & I feel all soft and happy inside about ___. & Eu me sinto leve e feliz por dentro quando penso em \\
\hline 19. & I am always thinking about & Estou sempre pensando em ___. \\
\hline 20. & If I were alway from ___ for a long time I would be very lonely. & Se eu ficasse longe de ___ _ por muito tempo, eu me sentiria muito sozinho. \\
\hline 21. & Sometimes I can't do my school work because I am thinking about & Às vezes, eu não consigo fazer meu dever de casa porque estou pensando em \\
\hline 22. & $\begin{array}{l}\text { I want ___ to know me, what I am thinking, what scares me, what I am } \\
\text { wishing for. }\end{array}$ & $\begin{array}{l}\text { Eu quero que _me conheça, conheça o que estou pensando, o que me } \\
\text { assusta e o que eu desejo. }\end{array}$ \\
\hline 23. & Knowing that ___ cares about me makes me feel more like I am OK. & Saber que ___ se importa comigo faz eu me sentir bem. \\
\hline 24. & I look at___ a lot to see if he/she likes me. & Eu olho bastante para ___ para ver se ele/ela gosta de mim. \\
\hline 25. & $\begin{array}{l}\text { If } \quad \text { needed help from me, I'd stop what I was doing, even if it was lots of } \\
\text { fun and go help him (her). }\end{array}$ & $\begin{array}{l}\text { Se__ precisasse da minha ajuda, eu pararia o que estivesse fazendo, mesmo } \\
\text { que fosse muito divertido, para poder ajudá-lo(a). }\end{array}$ \\
\hline 26. & _ can make me feel bubbly, like coke. & _ faz eu me sentir radiante, nas nuvens. \\
\hline 27. & When ___ is around I really want to touch him/her and be touched. & Quando ___ está por perto eu quero muito tocá-lo/a e ser tocado. \\
\hline 28. & Living without ___ would be very, very sad. & Viver sem ___ seria muito, muito triste. \\
\hline 29. & I want to hug ___ very, very tight. & Eu quero abraçar ___ muito, muito apertado. \\
\hline 30. & When I think ___ might be mad at me, I feel really sad. & Quando eu penso que ___ pode estar bravo(a) comigo, eu fico muito triste. \\
\hline
\end{tabular}

target population of adolescents between 14 to 18 years with the straight approval of all 30 items and the instructions. The expert panel evaluating the content-related validity of the scale found the JLS to be a conceptual measure of romantic love in children and adolescents and an equivalent measure of the original instrument with a Content Validity Index (CVI) higher than $90 \%$ for both the complete and the short forms of the JLS. Overall, the results suggest that the Juvenile Love Scale, translated and adapted to the Brazilian context, is pursuant to its proposal and suitable for application in the population of adolescents aged 14 to 18 years.

The use of the JLS can contribute to academic research and the widening understanding of various aspects of children and adolescent lives. Romantic love in adolescence is a recent topic of scientific interest with studies on the subject only becoming more significant in the last two decades. It is no longer possible to ignore such an impressive part of the lives of the young. According to a study conducted with American teenagers, about $25 \%$ of people in early adolescence affirmed they had a romantic relationship in the past 18 months, increasing for $53 \%$ in the 15 -year-olds, and reaching more than $70 \%$ of adolescents by age $18^{17}$. So, romantic love is a central topic of human development with adolescence being a critical age.

Being in a loving relationship in adolescence was associated with well-being in the short and the long term with benefits to the self-esteem and social integration ${ }^{18,19}$. On the other hand, young people who were involved romantically manifest more symptoms of depression than those who were not, with the probability of a first episode of major depression during adolescence being higher if a break-up had recently been reported ${ }^{18-20}$. Similarly, a conflictual relationship heightens an already stressful phase in life, a critical period for the development of various psychiatric disorders, especially concerning emotional disorders ${ }^{5,21-23}$. Therefore, a reliable and valid measure of the intensity of romantic love in adolescence is pivotal for a better understanding of the impact of love on several aspects of the adolescent life and their potential consequences.

By a clinical perspective, instruments such as the JLS can be useful to evaluate possible altered states and behaviors related to passionate love in adolescence. Brand et al.24, for example, says that adolescents' early-stage of intense romantic love can be highly comparable to hypomania, changing sleep patterns, mood, daily concentration, and daily activity. Also, especially in psychotherapy contexts, adolescents have a chance to talk about their feelings and thoughts about love, sex, and intimacy during the time they use to complete the scale. Besides, it allows therapists to have a chance to evaluate some skills that adolescents must come to develop'.

It is noteworthy to acknowledge some limitations in this translation and cross-cultural adaptation process. There is no consolidated or consensual theory on romantic love in children and adolescents. Therefore, the evaluation of the judges may be somewhat 
biased by their impressions and observations of passionate love. Moreover, some key expressions on the original content of the scale have no equivalent in Brazilian Portuguese, which hampered the translation process. In such cases, new expressions were developed to ensure the semantic quality issues. However, the translation process requires specific care in linguistic terms since it must preserve the idiosyncrasy of the language in which the scale will be translated to and have in mind the target community of interest. Moreover, the semantic adaptation of any scale or test is necessary to the extent that ensures language understanding to the population for which it is intended to ${ }^{25,26}$. Additionally, though the JLS was originally developed for children from 3 to 18 years, we have assured language clarity only for adolescents from 14 to 18 years. Thus, future studies are needed to ensure the adequacy of the Brazilian version of the JLS for a younger population. Also, the scale should be administered to a large sample of teenagers so that psychometric properties can be verified.

For the first time, a scale measuring romantic or passionate love in adolescents was adapted to the Brazilian context in this study. The JLS is a significant contribution to the study of the dimensions of love in the Brazilian population, as well as to understand the impact of love on the psychiatric phenomena that pervade life in this stage of development. After all, "few phenomena reflect the euphoria and the despair of this stage of life more poignantly than romantic relationships" 27 .

\section{Acknowledgments}

We thank professor Elaine Hatfield of the University of Hawaii for kindly agrees with the translation and cultural adaptation of the Juvenile Love Scale for the Brazilian context. This study was supported by INCT-MM that is financed by the Brazilian agencies for research development: Conselho Nacional de Desenvolvimento Científico e Tecnológico (CNPq), Coordenação de Aperfeiçoamento de Pessoal de Nivel Superior (Capes), and Fundação de Amparo à Pesquisa do Estado de Minas Gerais (Fapemig).

\section{Disclosure}

The authors declare that the research was conducted in the absence of any commercial or financial relationships that could be construed as a potential conflict of interest.

\section{References}

1. Hatfield E, Walster EH, Walster GW, Berscheid E. Equity: theory and research. Allyn \& Bacon, 1978.

2. Jankowiak WR, Fischer EF. A cross-cultural perspective on romantic love. Ethnology. 1992;31(2):149-55.

3. Fletcher GJ, Simpson JA, Campbell L, Overall NC. Pair-bonding, romantic love, and evolution the curious case of homo sapiens. Perspect Psychol Sci. 2015;10(1):20-36.

4. Fisher HE, Aron A, Brown LL. Romantic love: a mammalian brain system for mate choice. Philos Trans R Soc Lond B Biol Sci. 2006;361(1476):2173-86.

5. Fisher HE, Xu X, Aron A, Brown LL. Intense, passionate, romantic love: a natural addiction? How the fields that investigate romance and substance abuse can inform each other. Front Psychol. 2016;7:687.
6. Frascella J, Potenza MN, Brown LL, Childress AR. Shared brain vulnerabilities open the way for nonsubstance addictions: caving addiction at a new joint? Ann N Y Acad. Sci. 2010;1187:294-315.

7. de Boer A, van Buel EM, Ter Horst GJ. Love is more than just a kiss: a neurobiological perspective on love and affection. Neuroscience. 2012;201:114-24.

8. Hatfield E, Bensman L, Rapson RL. A brief history of social scientists attempts to measure passionate love. J Soc Pers Relatsh. 2012;29(2):143-64.

9. Hatfield E, Sprecher S. Measuring passionate love in intimate relationships. J Adolesc. 1986;9(4):383-410.

10. Sumter SR, Valkenburg PM, Peter J. Perceptions of love across the lifespan: differences in passion, intimacy, and commitment. Int J Behav Dev. 2013;37:417.

11. Casey BJ. Beyond simple models of self-control to circuit-based accounts of adolescent behavior. Annu Rev Psychol. 2015;66:295-319.

12. Dahl RE. Adolescent brain development: a period of vulnerabilities and opportunities. Ann N Y Acad Sci. 2004;1021:1-22.

13. Hatfield E, Young D. The juvenile love scale: a child's version of the passionate love scale. In: Fisher TD, Davis CM, Yaber WL, Davis SL (eds.). Handbook of sexuality-related measures (3rd Ed.). Thousand Oaks, CA: Taylor \& Francis, 2010. p. 466-8.

14. Sousa VD, Rojjanasrirat W. Translation, adaptation and validation of instruments or scales for use in cross-cultural health care research: a clear and user-friendly guideline. J Eval Clin Pract. 2011;17(2):268-74.

15. Polit DF, Beck CT. The content validity index: are you sure you know what's being reported? Critique and recommendations. Res Nurs Health. 2006;29(5):489-97.

16. Giusti E, Befi-Lopes DM. Tradução e adaptação transcultural de instrumentos estrangeiros para o Português Brasileiro (PB). Pro Fono. 2008;20(3):207-210.

17. Collins WA. More than myth: the developmental significance of romantic relationships during adolescence. J Res Adolesc. 13(1):1-24.

18. Collins WA, Welsh DP, Furman W. Adolescent romantic relationships. Annu Rev Psychol. 2009;60:631-52.

19. Joyner K, Udry JR. You don't bring me anything but down: adolescent romance and depression. J Health Soc Behav. 2000;41(4):369-91.

20. Monroe SM, Rohde P, Seeley JR, Lewinsohn PM. Life events and depression in adolescence: relationship loss as a prospective risk factor for first onset of major depressive disorder. J Abnorm Psychol. 1999;108(4):606-14.

21. Montgomery MJ. Psychosocial intimacy and identity from early adolescence to emerging adulthood. J Adolesc Res. 2005;20(3):346-74.

22. Lee FS, Heimer H, Giedd JN, Lein ES, Šestan N, Weinberger DR, Casey BJ. Adolescent mental health - Opportunity and obligation. Science. 2014;346(6209):547-9.

23. Pine DS, Fox NA. Childhood antecedents and risk for adult mental disorders. Annu Rev Psychol. 2015;66:459-85.

24. Brand S, Luethi M, von Planta A, Hatzinger M, Holsboer-Trachsler E. Romantic love, hypomania, and sleep pattern in adolescents. J Adolesc Health. 2007;41(1):69-76.

25. Pasquali L. Princípios de elaboração de escalas psicológicas. Arch Clin Psychiatry. 1998;25(5):206-13.

26. Mattos P, Segenreich D, Saboya E, Louzã M, Dias G, Romano M. Adaptação transcultural para o português da escala Adult Self-Report Scale para avaliação do transtorno de déficit de atenção/hiperatividade (TDAH) em adultos. Arch Clin Psychiatry. 2006;33(4):188-94.

27. Furman W, Brown BB, Feiring C. The development of romantic relationships in adolescence. Cambridge University Press, 1999. 